\title{
THE EU ACCESSION AND THE IMPACT ON ROMANIA'S FOREIGN TRADE AND COMPARATIVE ADVANTAGE
}

\author{
Adrian Negrea \\ University of Oradea \\ ngr_adrian@yahoo.com
}

\begin{abstract}
Romania's accession to the EU was a difficult task, but doable. However, the results of this accession are only now taking shape in the form of export orientation and competitiveness. This paper thoroughly analyses the aspects regarding Romania's foreign trade, based on the classification used by Lall (2000), with the data provided by the National Institute of Statistics on the Combined Nomenclature XXII sections, covering the 1991 - 2012 period. Furthermore, the paper addresses the concept of comparative advantage based on the Lafay indicator of Romania's foreign trade during 1991 - 2012. The indicator is calculated based on the statistical data offered by the National Institute of Statistics of the combined nomenclature with its XXII sections combined with Lall (2000) classification. The conclusions based on prior results try to assess whether the accession to the EU has had a beneficial or harmful effect on Romania's international trade and its comparative advantages.
\end{abstract}

\section{Keywords}

comparative advantage; competitiveness; commercial policy; trade flows; manufacturing

\section{JEL Classification}

F10; F14

\section{The EU accession}

Romania's accession to the European Union involved a series of decisions that had an impact on all international trade flows. The European Association Agreement stipulated that Romania needed to gradually eliminate all the customs duties that it registered with EU countries, and had to align national tariff duties to those applied in the EU. This process involved the implementation in Romania of the same trade policy valid for the rest of the European countries. Based on Berinde (2001, 2009) under the common commercial policy, Romania will have to understand and adapt to all three dimensions of the EU, namely: the multilateral, the bilateral and unilateral dimensions. Romania has implemented all the aspects of international negotiations, treaties and other agreements concluded by the EU accession. All agreements and treaties signed by Romania before joining will become void, Romania revoking them unilaterally.

The multilateral dimension refers to all the negotiations and agreements conducted under the auspices of the World Trade Organization (WTO), an organization of 157 countries and territories covering over $95 \%$ of world trade in goods and services. By the virtue of participating at the activities conducted under the patronage of the WTO, the EU is promoting the spirit and own values through international trade flows. At these meetings, a great emphasis is placed on the liberalization of international trade by removing tariff and non-tariff barriers on goods and services, covering also aspects of competition policy in the international market, to avoid distortions arising in the practice of unprincipled policies regarding trade. According to Giurgiu (2008) and Berinde (2009) the bilateral or regional dimension, adjacent to WTO negotiations, 
covers all the bilateral treaties between the EU and various international countries. Generally, the treaties are structured according to their purpose: Economic Partnership Agreements (EPA), Free Trade Agreements (FTA), Custom Union Agreements (CUA), and partnership and cooperation agreements. The same authors believe that the unilateral dimension combines all the facilities offered by the EU to developing or least developed countries, in order to encourage the export of goods and services of these countries towards the European internal market. The combination of the above mentioned factors, drove Romania to abolish its trade tariffs in a determined period of time, all the local companies suffering a steep production overhaul due to a massive increase of European imports. The impact of this accession on the country's foreign trade and comparative advantage will be studied in the following chapters.

\section{The impact on Romania's foreign trade}

Export trend analysis is based on the classification used by Lall (2000), with the data provided by the National Institute of Statistics regarding the Combined Nomenclature XXII sections, covering the 1991-2012 period. The following indicators are calculated as the sum of values registered by the specified nomenclature sections.

a. Resource-based manufacturing (RB): I Livestock and animal products; II Vegetable products; III Animal or vegetable fats and oils; IV Prepared foodstuffs, beverages and tobacco; V Mineral products; IX Wood and articles of wood, except furniture; X Pulp of wood, paper, paperboard and articles thereof; XIII Articles of stone, plaster, cement, ceramic, glass and similar materials.

b. Low-technology manufacturing (LT): VIII Raw hides and skins, leather, furskins and articles thereof; XI Textiles and textile articles; XII Footwear, headgear, umbrellas, and similar articles; XV Base metals and articles of base metals; XX Miscellaneous manufactured articles.

c. Medium technology manufacturing (MT): VI Chemical products; VII Plastic, rubber and articles thereof; XVI but only 84 boilers, turbines, engines, mechanical apparatus and devices, parts thereof; XVII Vehicles and associated transport equipment.

d. High-technology manufacturing (HT): XVI but only 85 machinery and mechanical appliances and electrical equipment; sound and television image recorders and reproducers; XVIII Optical, photographic, medical or surgical instruments and equipment and similar;

e. Other transactions (OT): XXII Goods non-included in the other sections of the Combined Nomenclature

The following tables will provide a glimpse on the evolution of trade flows during the analyzed period. The sum of values registered by the specified nomenclature sections mentioned above will be divided by the total amount of exports, so that all the results will be highlighted in percentage. Exports run by national producers during 1991 2012 can be analyzed based on the data presented in the table below. 


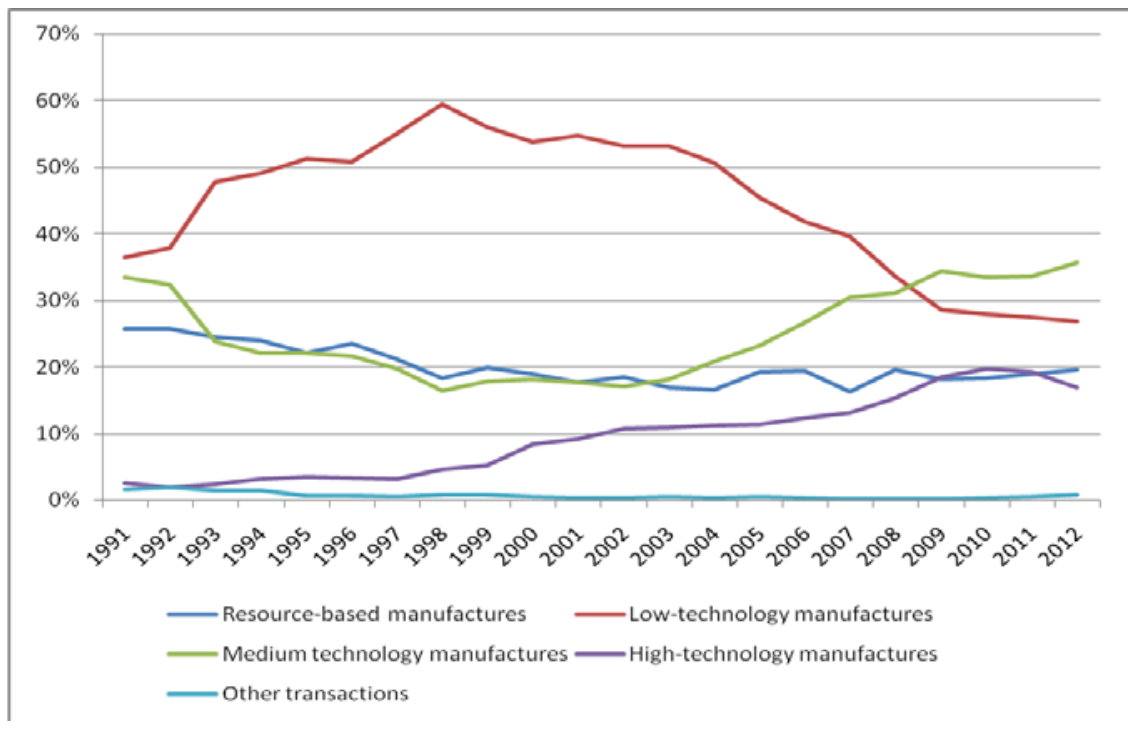

Figure 1 Exports run during 1991 - 2012 based on Lall (2000) classification, expressed in percentage

Source: Own computations based on the figures published by the National Institute of Statistics in the monthly Trade Bulletin

According to the table above, one can observe a cyclic evolution of Romanian exports to foreign markets. Based on the data presented, it can be seen that until 1998, lowtechnology manufacturing held the first position in total exports, but after that, registering a continuous regression in the next period. Also, the same table shows how medium technology manufacturing value declines in the period $1992-2003$, followed by a period of exponential growth, a trend that will continue in the near future. The most significant increase is recorded by high-technology manufacturing. This development can be caused by foreign direct investment in domestic production capacity, increasing its value, especially in the automotive industry. This trend can be seen in the Table 1, which analyzes the evolution of Romania's comparative advantages to the rest of the world. This table shows a shift from a resource-based manufacturing and low-technology manufacturing exporting economy, to a medium and high-technology technology manufacturing exporting economy, as in similar cases recorded in the developed western economies.

Based on future governmental intervention through fiscal subsidies and credit guaranties will encourage future investment in this field, augmenting the sustainable development of national producers and increasing the value of exports of medium and high technology manufacturing products. Passing on to the analysis of imports, we see a different picture of what was presented previously. According to the data analyzed in the table below, the highest share in total imports is held by resourcebased manufacturing. This dominant trend in total imports continued until 1997, and may ascribe on the consumer goods shortages and industrial plant closures that the Romanian market was facing at the time. However, this trend does not explain how a country endowed with natural resources, holding the fifth largest agricultural area in the EU, registers the highest values of imports in the resource-based manufacturing section. We consider that the lack of national producers and the closures combined with the de-industrialization effect have made Romania suffer a decline in this field. 
Table 1 Evolution of Lafay indicator regarding Romania's global trade between 1991 - 2012, based on Lall (2000) classification

\begin{tabular}{|c|c|c|c|c|c|c|c|c|c|c|c|c|c|c|c|c|c|c|c|c|c|c|}
\hline & 1991 & 1992 & 1993 & 1994 & 1995 & 1996 & 1997 & 1998 & 1999 & 2000 & 2001 & 2002 & 2003 & 2004 & 2005 & 2006 & 2007 & 2008 & 2009 & 2010 & 2011 & 2012 \\
\hline $\begin{array}{l}\text { Resource- } \\
\text { based } \\
\text { manufacturing }\end{array}$ & $-0,175$ & $-0,123$ & $-0,107$ & $-0,076$ & $-0,072$ & $-0,057$ & $-0,050$ & $-0,044$ & $-0,020$ & $-0,034$ & $-0,042$ & $-0,028$ & $-0,037$ & $-0,039$ & $-0,035$ & $-0,028$ & $-0,032$ & $-0,030$ & $-0,032$ & $-0,026$ & $-0,025$ & $-0,029$ \\
\hline $\begin{array}{l}\text { Low- } \\
\text { technology } \\
\text { manufactu- } \\
\text { ring }\end{array}$ & 0,129 & 0,106 & 0,146 & 0,140 & 0,145 & 0,134 & 0,144 & 0,151 & 0,121 & 0,120 & 0,120 & 0,110 & 0,118 & 0,118 & 0,102 & 0,090 & 0,079 & 0,056 & 0,035 & 0,032 & 0,028 & 0,028 \\
\hline $\begin{array}{l}\text { Medium } \\
\text { technology } \\
\text { manufactu- } \\
\text { ring }\end{array}$ & 0,064 & 0,042 & $-0,017$ & $-0,034$ & $-0,041$ & $-0,047$ & $-0,053$ & $-0,065$ & $-0,064$ & $-0,050$ & $-0,059$ & $-0,071$ & $-0,072$ & $-0,072$ & $-0,063$ & $-0,052$ & $-0,050$ & $-0,037$ & $-0,014$ & $-0,013$ & $-0,015$ & $-0,008$ \\
\hline $\begin{array}{l}\text { High- } \\
\text { technology } \\
\text { manufactu- } \\
\text { ring }\end{array}$ & $-0,023$ & $-0,021$ & $-0,025$ & $-0,031$ & $-0,030$ & $-0,027$ & $-0,035$ & $-0,038$ & $-0,038$ & $-0,038$ & $-0,019$ & $-0,013$ & $-0,011$ & $-0,008$ & $-0,006$ & $-0,001$ & 0,002 & 0,012 & 0,011 & 0,007 & 0,011 & 0,006 \\
\hline $\begin{array}{l}\text { Other } \\
\text { transactions }\end{array}$ & 0,004 & $-0,004$ & 0,003 & 0,001 & $-0,002$ & $-0,004$ & $-0,007$ & $-0,005$ & 0,001 & 0,001 & 0,001 & 0,002 & 0,002 & 0,001 & 0,001 & 0,001 & 0,000 & 0,000 & 0,000 & 0,001 & 0,001 & 0,003 \\
\hline
\end{tabular}




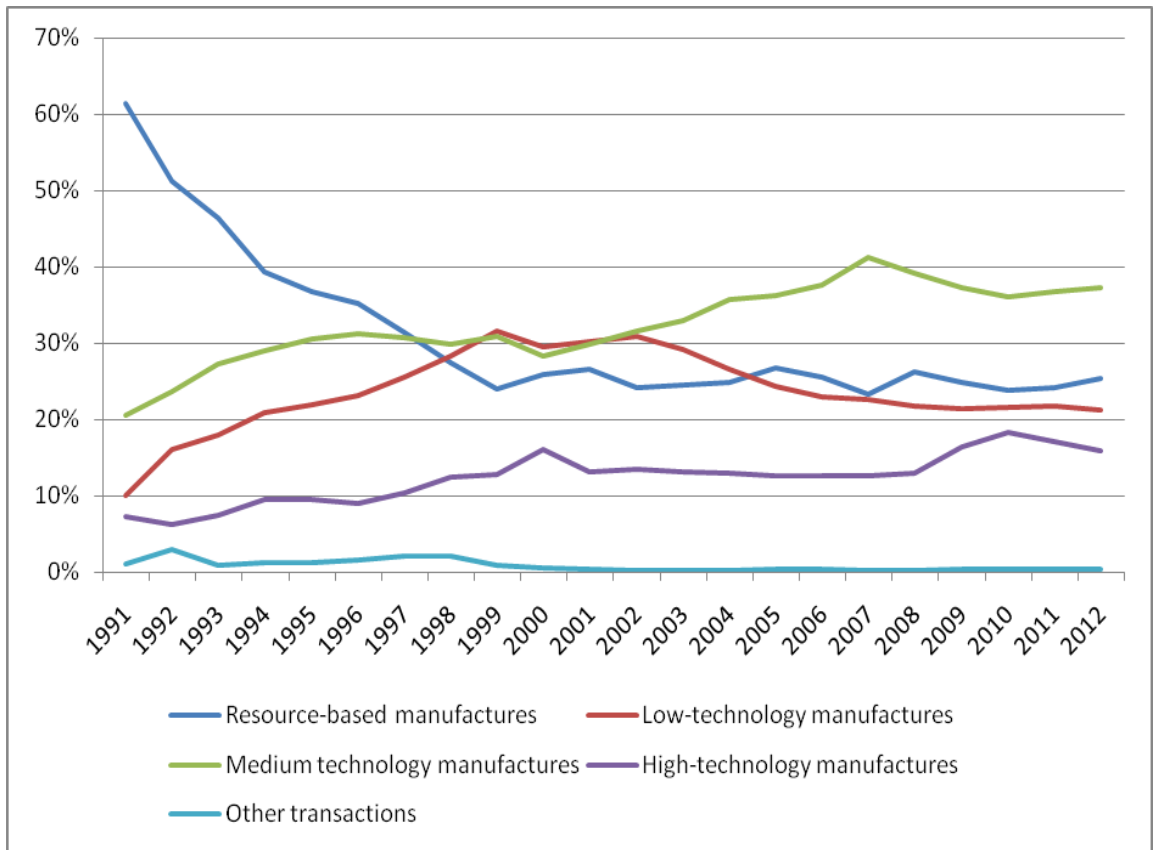

Figure 2 Imports run during 1991 - 2012 based on Lall (2000) classification, expressed in percentage

Source: Own computations based on the figures published by the National Institute of Statistics in the monthly Trade Bulletin

Further analyzing the value of imports from the low-technology manufacturing perspective, the trend is apparent cyclic, with periods of growth, maturity and decline. The peak of low-technology manufacturing imports is achieved in 1999, and that due only to an increase in textile Lohn contracts. The growth of medium technology manufacturing value is recorded in the period $2000-2008$ and occurs due to extremely high demand from local consumers of goods, especially cars from the European market. If the combined nomenclature is analyzed, it can be seen that the value of auto vehicles imports have tripled from 2004 to 2007. The decline is due to the financial crisis, but as one can see, the trend is towards growth, a sign that once economic growth returns the consumption growth based on imports will soon follow. High-technology manufacturing tend to grow during the years 1991 - 2000, after which a stable period in terms of the percentage held in total imports during the period 2001 - 2008 follows, although in terms of value, it records an annual growth. Starting with 2009, their share in total imports is beginning to rise, a sign that this segment can climb on the podium as second place in importance, ahead of resourcebased and low-technology manufacturing. We consider that this would be a positive development, but only if the imported goods are intended for a productive purpose, not only for personal consumption.

\section{Romania's comparative advantages}

The Lafay indicator can be used when considering the comparative advantages of the commercial flows, in order to express the competitiveness of a certain field of the economy compared to the rest of the world, according to the formula: 


$$
L F I_{j}^{i}=100 \cdot\left[\frac{x_{j}^{i}-m_{j}^{i}}{x_{j}^{i}+m_{j}^{i}}-\frac{\sum_{j=1}^{N}\left(x_{j}^{i}-m_{j}^{i}\right)}{\sum_{j=1}^{N}\left(x_{j}^{i}+m_{j}^{i}\right)}\right] \cdot \frac{x_{j}^{i}+m_{j}^{i}}{\sum_{j=1}^{N}\left(x_{j}^{i}+m_{j}^{i}\right)}
$$

Where:

$x_{i}$ - represents the exports of the group or product $j$;

$m_{i}$ - represents the imports of the group or product $j$.

Based on the previous formula and in conjunction with the data provided by the National Institute of Statistics regarding the Combined Nomenclature (CN) for all the XXII classes, the data registered in euro during 1991 - 2012, and combined with Lall (2000) classification, the Lafay indicator was calculated in Table 2 in the annex. The table presents huge discrepancies between the sections. As it can be seen, Romania's comparative disadvantages in the resource-based manufacturing are pictured as chronic, during the entire period analyzed. This represents a big question mark for the decision makers, because Romania has the fifth largest agricultural area and is endowed with all the Earth's natural resources. I consider that not all the agricultural land is cultivated, and there is a lack of production companies in this field, able to process the goods and attach a higher economic value. Low-technology manufacturing seems to be the sector that registers a comparative advantage during the entire analyzed period. This phenomenon is due to low payments that are received in this sector. Because this is a high labor intensive sector, if the salaries went up, Romania would lose its competitive edge in favor of other Eastern Asian countries. The medium technology manufacturing sector seems to register a chronic comparative disadvantage, but this trend is experiencing reparation. Due to the increased exports of cars, and a severe contraction regarding imports due to the financial crisis, the figures show a future transformation from comparative disadvantages to comparative advantages in the near future, and only if the exports increase. A point to notice is that the analysis of comparative advantage indicators of Romania shows a complete absence regarding the comparative advantages in the medium and high technology intensive manufacturing, but highly competitive in the labor intensive low-technology manufacturing.

The question that should be asked is whether it is worth encouraging these sectors in which a comparative advantage is registered, or should the government focus on encouraging and developing the medium and high-technology manufacturing sectors?

\section{Conclusions}

The conclusions of this paper state that Romania's economy need a more effective change of the production process. It is inadmissible that a country with the fifth largest agricultural area and endowed with all the natural resources register massive imports of resource - base manufacturing. At the beginning of the 1990s that was due to a lack of consumer products on the Romanian market, but nowadays, this is due to a lack of producers in this sector. The value of imported mineral resources, holding the most significant percentage when this indicator is decomposed, highlights the negative effect of the restructuring process. Due to lack of interest, many industrial complexes vanished because they were privatized and sold for scrap metal, determining the rest of the economy to import mineral resources from abroad. The 
second place held by this sector in overall imports with the perspective of holding this place for the next period, it's a problem that needs to change. In my personal opinion, measures that attract foreign direct investments in this sector combined with governmental credit guarantees and a lax fiscal policy should boost internal production, changing the course from a comparative disadvantage to a comparative advantage.

Attaining and maintaining a comparative advantage in the low technology manufacturing sector through the hole analyzed period, is possible only because of the low wages in these sectors, especially textiles and footwear. An increase of wages through governmental influence to 1.000 lei, would influence negatively the future maintenance of the comparative advantage. If this will take place, the investors may shift their orders to lower wages Asian countries. A remarkable twist from comparative disadvantage to comparative advantage will be recorded in the mediumtechnology manufacturing, due to foreign direct investments realized by Renault and Ford. This trend will be maintained in the next period, due to a planned increase in the production of auto vehicles suggested by the two renowned producers. In my opinion, this sector should benefit from government intervention through stimulating financial schemes and credit guarantees, in order to increase production of internal suppliers, in order to maintain a high volume of internal intermediate costs, that will help a sustainable development of the national economy.

\section{References}

Berinde, M., Giurgiu, A. (2005), Aderarea României la Uniunea Europeană, Oradea, Editura Universităţii din Oradea.

Berinde, M. (2009), Uniunea Europeană și integrarea economică regională, București, Editura Tribuna Economică.

Burnete, S. (1999), Comerț internaţional. Teorii, modele, politici, București, Editura Economică.

Cerchez, O. (2007), Eficiența economică a comerțului exterior, București, Editura Logos.

Drăgan, G. (2004), Fundamentele comerţului internaţional, Bucureşti, Editura ASE.

Giurgiu, A. (2008), Comerț internaţional și politici comerciale, Oradea, Editura Universităţii din Oradea.

Lall, S. (2000), The Technological Structure and Performance of Developing Country Manufactured Exports, 1985-1998, Oxford Development Studies.

Porter, M. (2004), Competitive Strategy: Techniques for Analyzing Industries And Competitors, Gardners Books.

Sută, N. (2000), Comerț internațional și politici comerciale contemporane volumul I, București, Editura Eficient.

Sută, N. (2000), Comerț internațional și politici comerciale contemporane volumul II, București, Editura Eficient.

This paper is suported by the Sectorial Operational Programme Human Resources Development (SOP HRD), financed from the European Social Fund and by the Romanian Government under the contract number SOP HRD/107/1.5/S/82514. 